\title{
Phytoplankton dynamics and periodicity in two cascading warm-water reservoirs from 1989 to 1997 - taxonomic and functional (C-S-R) patterns, and determining factors
}

\author{
RC Hart \\ School of Biological and Conservation Sciences, University of KwaZulu-Natal, Pietermaritzburg 3209, South Africa
}

\begin{abstract}
The composition and abundance of distinctive planktonic autotrophs (ca 60 taxa) were examined at roughly fortnightly intervals in two sizeable reservoirs (Midmar and Albert Falls) on the uMngeni River, KwaZulu-Natal, between 1989 and 1997. The dynamics of community structure and abundance were examined in both taxonomic and functional (C-S-R) terms in relation to physical abiotic variables (thermal stratification, light climate, water level) and biotic influences of predation (zooplankton abundance).

Annual periodicity was exhibited by most taxa apart from Cryptomonas, although patterns tended to be indistinct and inter-annual repeatability was generally weak - in line with year-to-year and between-system environmental variability. Water level fluctuation, with concomitant change in stratification intensity and hydraulic mixing and accompanying changes in water clarity associated with suspended sediment levels was clearly a major (direct and indirect) determinant of phytoplankton composition and abundance. The influence of top-down controls as inferred from phytoplankton-zooplankton relationships was fundamentally different in the two reservoirs - potentially stimulatory in Midmar, but clearly regulatory in Albert Falls, where episodic collapses of Daphnia populations resulted in chlorophyll values well into the eutrophic level range. In addition to annual patterns, changes in chlorophyll content implied progressive long-term changes in trophic status, especially in Albert Falls, with the emergence of various 'new' taxa (and/or higher peak densities of others).

Consideration of phytoplankton dynamics in terms of functional groups offers certain advantages over conventional phyletic taxonomic analyses, although algal response forecasting by either approach appears potentially constrained by hydrological variability. Site-specific bio-monitoring, possibly using new rapid technologies, is likely to be necessary for ongoing management purposes until predictive capabilities under regionally characteristic conditions improve. Despite limitations, functional classification proffers faster advances to this end than conventional taxonomic appraisal.
\end{abstract}

Keywords: algae, plankton, dynamics, community assemblage, reservoir limnology, water quality, biomonitoring

\section{Introduction}

By virtue of high taxonomic diversity, and rapid response of most of its constituent members to environmental actuators and drivers (nutrients, light, temperature, turbulence, and pollutants), phytoplankton (in its collective sense of all planktonic autotrophs including cyanobacteria) has become widely recognised as a reliable 'bio-indicator' of water quality for a variety of purposes (Dubelaar et al., 2004). Man-made lakes (river-impoundments or river-reservoirs, colloquially referred to as "Dams") are the predominant source of freshwater for all uses (irrigation, industry, etc.), including human consumption (drinking water) in South Africa (DWA 1986). Despite this, little information exists concerning the composition and periodicity of their phytoplankton (Allanson et al., 1990). Investigations into this topic in South Africa commenced on natural coastal lakes - the pristine L. Sibaya (Hart and Hart, 1977), and subsequently Princess Vlei, an anthropogenically perturbed system (Harding, 1992). Studies published on this collective topic for South African reservoirs have been limited in number and/or temporal extent. These mostly involve 'extreme' environments

II +2733 260-5117; fax: +2733 260-5105;

e-mail: hartr@ukzn.ac.za

Received 30 July 2005; accepted in revised form 6 December 2005. such as the hypertrophic Hartbeespoort Dam (NIWR, 1985; Chutter and Roussouw ,1992), the eutrophic Roodeplaat Dam (Pieterse and Röhrbeck, 1990) and Loch Lomond (Vos and Roos, 2005), as well as certain water-bodies with high sediment turbidity - Lake le Roux (Allanson and Jackson, 1983) and Spioenkop (Hart, 1999). Extended algal studies of planktonic algae in the slow- flowing Vaal River Barrage have also involved eutrophic waters with elevated salinity (Roos and Pieterse, 1996; Pieterse and Janse van Vuuren, 1997). General concerns regarding water quality in SA impoundments have been largely subsumed in determinations of chlorophyll content - an integral measure of autotroph abundance - rather than in systematic analyses of its constituent members. Substantial regional databases containing such information exist (e.g. Graham et al., 1998) but appear not to have been interrogated regarding intrinsic temporal detail.

Water treatment costs and protocols are well known to vary according to its constituent suspended particles - biogenic autotrophs, and, commonly in South Africa - suspended mineral sediments. These attributes influence the filtration efficiency and capacity of water treatment plants, and may impose the need to combat objectionable tastes and odours (e.g. Graham et al., 1998; Barrell et al., 2004). Internationally, there is increasing prominence and concern about the growing and almost ubiquitous presence of toxins including geosmin, microcystin and cylindrospermopsin derived from cyanophytes (Baker et al., 1994; Shaw et al., 1999; Steffensen et al., 1999; Frank and 


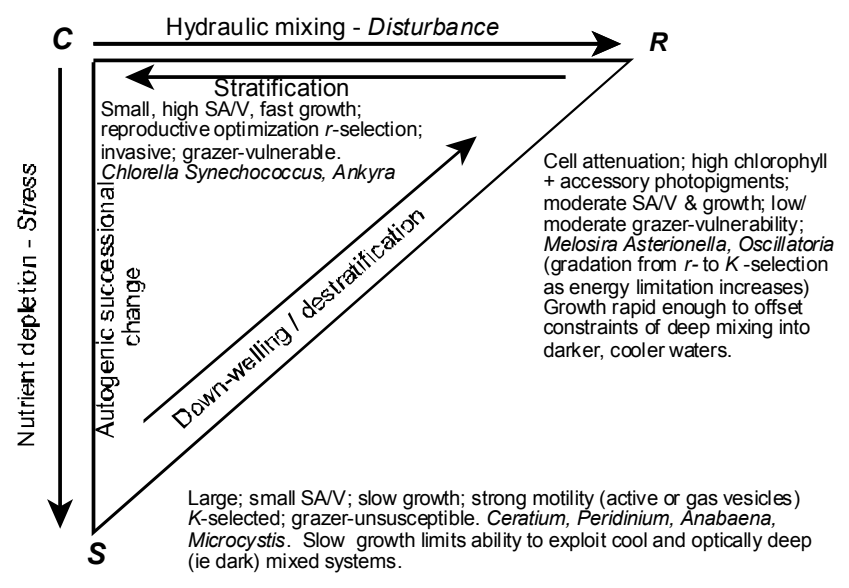

Figure 1

Graphical representation of the C-S-R functional concept as applicable to phytoplankton (after Reynolds, 1996)

Wolf, 2002). "The tiny cyanobacteria, being a geological force in the dynamics of the globe, will continually become more central to the modern world and be applied more closely, affecting our lives" (Skulberg, 2005). With growing awareness of the increasing socio-economic risks posed by toxic algae and Harmful Algal Blooms (HAB) to aquatic organisms, human health (Falconer and Humpage, 1996, 2001) and aquatic environments (Fitzgerald et al., 1999), the acronym HAB has become a contextually familiar term in water management circles (e.g. Hallegraeff,1993; Anderson et al., 2002; Hoagland et al., 2002). Overall, predictive understanding of temporal changes in composition and abundance of phytoplankton is accordingly a valuable tool in water resource management.

Here, seasonal changes in phytoplankton in two cascading reservoirs are reported, and the concordance of observed changes in broad taxonomic composition with the theoretical constructs embraced in the C-S-R functional models of pelagic vegetation is explored (Reynolds, 1996; 1997; 1999). Periodicity patterns in these non-eutrophic monomictic systems are documented and examined to expand locally relevant ecological information on phytoplankton under conditions of contrasting stratification intensity and during different phases of hydrological regime (flood, drought). The value of functional C-S-R monitoring to monitoring is explored as a general alternative to specialist systematic analyses, potentially opening prospects for submersible FluoroProbe technology and/or or flow cytometry (Dubelaar et al., 2004; See et al., 2005) as shortcuts to routine phytoplankton categorisation.

\section{Conceptual framework}

Building on a framework established for terrestrial plants (Grime, 1979), the seminal work of Reynolds $(1984 ; 1996 ; 1997)$ has led to the common recognition today of three classes of planktonic autotrophs (Fig. 1), namely - the competitive Colonist (C), the acquisitive Stress tolerant (S) and the disturbance-tolerant or attuning Ruderal (R) elements, the respective morphologies, physiologies and 'behaviours' of which accord with these respective life-styles, and appositely, with his initials - Colin Stanley Reynolds. These classes are positional apices of a triangular space matrix (Fig. 1) whose primary axes reflect energy availability, resource availability, and disturbance. However, classes are not necessarily discrete or exclusive. Rather, species show adaptive and evolutionary trends that bias their performances towards one or other of the primary strategies, within which gradations and intermediates exist. Taxa can occupy the apices themselves (C, R or S), or range between the $\mathrm{C}$ and $\mathrm{R}(\mathrm{C}-\mathrm{R})$, the $\mathrm{C}$ and $\mathrm{S}(\mathrm{C}-\mathrm{S})$ or the $\mathrm{S}$ and $\mathrm{R}$ (S-R) apices (Fig. 1), depending on their adaptability to and selection by the controlling influences of temporal changes in resource and/or energy availability.

Midmar and Albert Falls Dams, the study sites for this investigation (see below) differ in stratification intensity and susceptibility to hydraulic disturbance, while inter-annual differences in suspended sediment loadings and variations in water depth impart additional dimensions of variability. All these factors serve to create a variable habitat template (Southwood, 1977) against which to examine and test the veracity of the C-S$\mathrm{R}$ functional model (Reynolds, loc cit). The predictions amenable to comparative testing within and between these reservoirs include the following:

- Relatively more of the community will consist (both intraand inter-annually) of ruderals in Midmar than in Albert Falls

- Stress tolerators will contribute relatively more to the community in Albert Falls than in Midmar

- In both lakes, ruderals will assume greater relative importance during drought conditions of lowered water-level (higher suspended sediment contents, and reduced stratification intensity) than during high water levels

- Within each lake, an inverse relationship will exist between the abundance of grazing zooplankton and small (colonist) phytoplankton taxa, while the abundance of large (stress-tolerant) autotrophs will either be unrelated or directly related to the abundance of grazing zooplankton.

It was additionally expected that the resolution of confounding influences of nutrient limitation imposed by reservoir trophic status per se (i.e. extrinsic consequence of general reservoir nutrient status) as opposed to limitation associated with stratification (i.e. intrinsic temporal effects within a reservoir) might be assisted by the comparative study. On this basis it can be premised that:

- Stress-tolerant taxa will either be more abundant:

- In Midmar than Albert Falls (if lower extrinsic nutrient level is the principal selective influence);

- In Albert Falls than Midmar (if selection principally reflects the intrinsic limitation imposed by stratification); or

- Will make quasi comparable contributions to assemblages in both reservoirs (if the distinction between intrinsic and extrinsic factors is blurred or confounded).

\section{Materials and methods}

\section{Study sites}

Midmar (MID) and Albert Falls (ALF) are two consecutive reservoirs on the upper uMngeni River, in KwaZulu-Natal (Fig. 2). Their comparative morphometry at full supply level (FSL) and relevant biophysical information is compared in Table 1. The most salient differences relate to reservoir age (MID $>A L F)$, elevation (MID $>$ ALF), catchment area and lake surface area (ALF $>$ MID), volume (ALF $>$ MID) and theoretical flushing times (ALF $>$ MID); conversely, mean depths are remarkably similar. Largely as a result of differences in physiographic elevation, water temperatures of Albert Falls are consistently warmer than Midmar by around 1.8 to $2.0^{\circ} \mathrm{C}$ (Hart, 1994; 2000), with resultant increases in stratification intensity and relative physical 


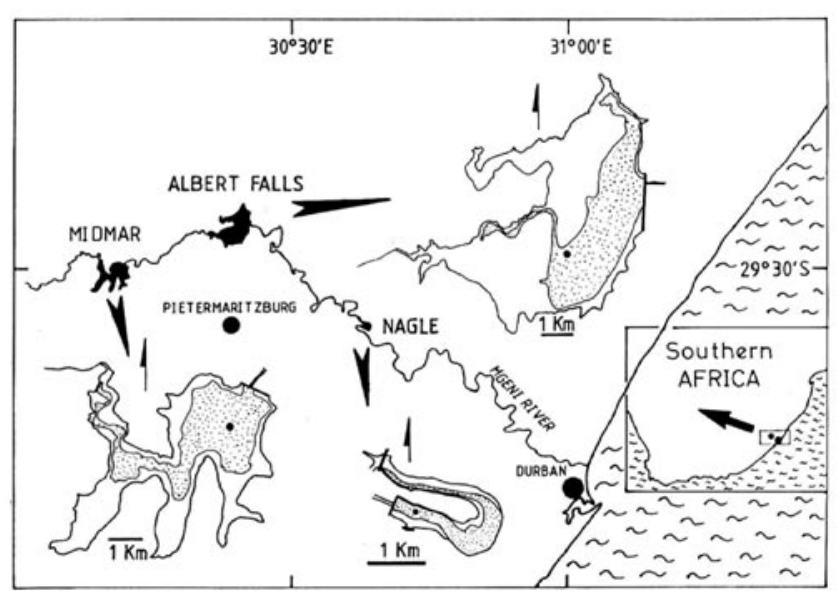

Figure 2

Location and outline maps of the study reservoirs, showing routine sampling sites $(\bullet)$ in relation to general bathymetry. Water deeper than $13.5 \mathrm{~m}$ is stippled.

stability (Hart, 2001;2004). A comparative summary of variables for these lakes listed by Graham et al. (1998) includes useful chemical information.

\section{Sampling}

Routine sampling was undertaken at a single deep-water offshore site broadly representative of each lake's open waters $\left(29^{\circ} 30^{\prime} \mathrm{S}\right.$, $30^{\circ} 12^{\prime} \mathrm{E}$ on Midmar, and $29^{\circ} 26^{\prime} \mathrm{S}, 30^{\circ} 26^{\prime} \mathrm{E}$ on Albert Falls) at roughly fortnightly intervals from mid-1989 to mid-1998. Sampling generally took place between 10:00 and 14:00. Vertical profiles of temperature and dissolved oxygen were measured with an air-calibrated YSI model 58 electronic meter. Secchi depth transparency (SD) was measured using a white disk of $250 \mathrm{~mm}$ diameter. Vertical profiles of radiation at appropriate depth intervals were made with a Lambda model LI 188B radiometer to yield measures of underwater attenuation of light (PAR; 400-700 nm). Spectral characteristics were determined intermittently using selective red (540-750, midpoint $670 \mathrm{~nm}$ ), green (470-690, midpoint $550 \mathrm{~nm})$ and blue $(370-510$, midpoint $443 \mathrm{~nm})$ Jena-Schott filters to identify the most penetrating component $\left(\mathrm{K}_{\mathrm{mpc}}\right)$. Downwelling attenuation coefficients $\left(K_{\mathrm{d}} \cdot \mathrm{m}^{-1}\right)$ were determined as:

$$
K_{\mathrm{d}}=\frac{\ln I_{0}-\ln I_{\mathrm{z}}}{\mathrm{z}}
$$

where:

$$
\begin{aligned}
I_{0}= & \text { light intensity at depth } 0 \mathrm{~m} \\
I_{\mathrm{z}}= & \text { light intensity at depth } \mathrm{z} \mathrm{m} \\
\mathrm{z}= & \text { depth interval between measured } \\
& \text { values. }
\end{aligned}
$$

Integral water samples of the uppermost $3 \mathrm{~m}$ were collected in a tube sampler (Zohary and Ashton, 1985) at a single offshore deep-water site in each lake (see Hart, 1992). After shaking to homogenise it, the sample was decanted into a freshly washed opaque $2 \ell$ plastic container, and a new $50 \mathrm{~m} \ell$ plastic bottle for subsequent chlorophyll extraction and phytoplankton analysis, respectively. The smaller bottle was fixed on site with $1.0 \mathrm{~m} \ell$ Lugol's solution; the larger was stored in the dark in an insulated 'cold-box'.

\section{Sample analyses}

Chlorophyll content was determined by vacuum filtration generally of $1000 \mathrm{ml}$ of the hose-pipe sample through glass fibre filter pads $(\mathrm{GF} / \mathrm{C})$ within $3 \mathrm{~h}$ of collection. Filter pads were immediately immersed in $95 \%$ methanol and stored in the dark. Chlorophyll was extracted by boiling, and spectrophotometric measurements of optical absorbance (E) of the extract were made at 665 and $750 \mathrm{~nm}$ in a $40 \mathrm{~mm}$ light path after centrifugation. Chlorophyll concentration $\left(\mu \mathrm{g} \cdot \ell^{-1}\right)$ was determined, disregarding degradation products as:

$$
\text { Chlorophyll } \alpha=\frac{13.9 \times 8.9 \times\left(\mathrm{E}_{665}-\mathrm{E}_{750}\right) \times \mathrm{v}}{\mathrm{V} \times 1}
$$

where:

$\mathrm{v}=$ volume of solvent $(\mathrm{m} \ell)$

$\mathrm{V}=$ volume of sample filtered $(\ell)$

$1=$ photometric light-path length $(\mathrm{mm})$.

Phytoplankton abundance and composition was determined using conventional (Ütermohl) inverted microscopy (Lund et al., 1958). Sample aliquots of $10 \mathrm{~m} \ell$ were left overnight for particle sedimentation, and thereafter successive transects were examined microscopically at 400X until at least 200 'units', or roughly 100 'units' of the numerically dominant taxon on each sample date had been counted. 'Units' comprised individual uni-cells, filaments and other colony types as applicable, with no routine distinction of colony size within a taxon, although subjective rankings of colony size were noted. Taxa were routinely identified to generic level, and further distinguished to (unnamed) morpho-species level. Additionally, on the basis of published data and/or morphological inference they were assigned to an appropriate functional class - C, S or R (Reynolds, 1996; 1997), as detailed in Table 2 (modified from Hart (1996) after Reynolds, 2005). Counts were translated into density estimates of cells and colonies, per $\mathrm{m} \ell$. No correction was made for counting biases associated with the obscuring influence (especially on smaller taxa) of variable levels of mineral turbidity, which was high on some sampling dates. Some 60 taxa were recorded during the study. Only the more frequently present and/or abundant taxa are considered in the following account. Taxa were selected for consideration on the basis of an "inclusion threshold" index, calculated as the product of their percentage occurrence and mean density $\mathrm{m}^{-1}$ on all 183 sampling dates. Across all taxa, this
TABLE 1

Synopsis of physical and morphological characteristics of the study reservoirs (after Walmsley and Butty, 1980), with supplementary retention time estimates $\left({ }^{*}\right)$ based on multiannual inflow records (Graham et al., 1998)

\begin{tabular}{|l|c|c|}
\hline & \multicolumn{2}{|c|}{ Reservoir } \\
\hline Attribute: & Midmar & Albert Falls \\
\hline Latitude and Longitude & $29^{\circ} 30^{\prime} \mathrm{S} 30^{\circ} 12^{\prime} \mathrm{E}$ & $29^{\circ} 26^{\prime} \mathrm{S} 30^{\circ} 25^{\prime} \mathrm{E}$ \\
\hline Year of impoundment & 1964 & 1976 \\
\hline Catchment area (km $\left.{ }^{2}\right)$ & 928 & 728 \\
\hline Altitude (m amsl) & 1044 & 656 \\
\hline Surface area at full supply (ha) & 1559 & 2385 \\
\hline Mean depth at full supply (m) & 11.4 & 12.3 \\
\hline Maximum depth at full supply $(\mathrm{m})$ & 22.3 & 24.6 \\
\hline Storage capacity at full supply $\left(10^{6} \mathrm{~m}^{3}\right)$ & 177.2 & 293.6 \\
\hline Theoretical mean water retention time (d) & $318 / 367^{*}$ & $562 / 512^{*}$ \\
\hline
\end{tabular}




\begin{tabular}{|c|c|c|}
\hline \multicolumn{3}{|c|}{$\begin{array}{l}\text { TABLE } 2 \\
\text { Functional class assignments of phytoplankton genera } \\
\text { recorded from Midmar and Albert Falls during this study }\end{array}$} \\
\hline Ruderals (R) & Colonists (C) & Stress tolerators (S) \\
\hline Cyclotella & Ankistrodesmus & $(\mathrm{C} \leftrightarrow \mathrm{S})$ Anabaena \\
\hline Aulacoseira & Closteriopsis & $(\mathrm{C} \leftrightarrow \mathrm{S})$ Merismopedia \\
\hline Fragilaria & Crucigenea & Microcystis \\
\hline Tabellaria & Shröderia & Nodularia \\
\hline Closterium & Tetraëdron & Ceratium \\
\hline Cosmarium & Oocystis $(\mathrm{C} \leftrightarrow \mathrm{S})$ & Peridinium \\
\hline \multirow[t]{4}{*}{ Staurastrum } & $(\mathrm{R} \leftrightarrow \mathrm{C})$ Arthrospira & Trachelomonas \\
\hline & $(\mathrm{R} \leftrightarrow \mathrm{C})$ Coelastrum & \\
\hline & $(\mathrm{R} \leftrightarrow \mathrm{C})$ Scenedesmus & \\
\hline & $\begin{array}{l}(\mathrm{R} \leftrightarrow \mathrm{C}) \text { Cryptomonas } \\
(\mathrm{C} \leftrightarrow \mathrm{S})\end{array}$ & \\
\hline
\end{tabular}

differences in annual temperature range, and stratification intensity are consistent with differences in lake elevation and wind-shelter aspect; ALF was consistently warmer, and showed stronger accompanying stratification than MID.

Water transparency varied considerably, as evidenced by the wide variations in Secchi depth visibility (Fig. 3b). Transparency varied seasonally, broadly in relation to thermal stratification events; autumnal overturn in particular, was mirrored in rapid reductions of Secchi depth. Water clarity also increased sharply following rising water levels after prolonged drought partly owing to reduced sediment re-suspension in increasingly deep waters, and despite inflow-related sediment inputs (especially into MID, which effectively functions as a pre-impoundment for ALF downstream). Significant hydrological variability was evident during the study period, which commenced and terminated in 'wet' year phases effectively bracketing a prolonged 'low water phase', especially pronounced in ALF (Fig. 3b).

index averaged 1656 in MID (range of 4 to 18 150), and 2297 (1 to 24 927) in ALB. An arbitrary cut-off threshold value of 50 for this index was applied to all taxa other than Ceratium and Peridinium.

Detailed enumeration of zooplankton collected in vertical net hauls was undertaken as described elsewhere (Hart, 2001, 2004). For the present study, counts were converted to estimates of biomass $\left(\mathrm{mg} \cdot \mathrm{m}^{-2}\right.$ DW) using the following coefficients: Daphnia pulex and D. longispina - individuals collectively assigned $35 \%$ of the date-specific mean biomass values of egg-bearing females, computed as $1.51+2.76 \ln L$ (where $L$ = body length, $\mathrm{mm}$ ); D. laevis $-7.5 \mu \mathrm{g} \cdot$ ind $^{-1}$; Ceriodaphnia, Diaphanosoma and Moina$2.5 \mu \mathrm{g} \cdot$ ind $^{-1}$; rotifers $-0.1 \mu \mathrm{g} \cdot$ ind $^{-1}$; nauplii, ovigerous female and other life stages of cyclopoid copepods $-0.25,2$ and $1 \mu \mathrm{g} \cdot$ ind $^{-1}$; nauplii, C1-C3, C4-C5, adult male and adult female stages of calanoid copepods - 1, 3.7, $5.9,10$ and $20 \mu \mathrm{g} \cdot \mathrm{ind}^{-1}$. As obligate predators, Chaoborus larvae were excluded from the zooplankton biomass calculation.

\section{Data analysis}

Conventional parametric and non-parametric statistical tests (Zar, 1984; Quinn and Keough, 2002) were made using SPSS11.5 for Windows. Graphs were compiled using SigmaPlot V9.

\section{Results and discussion}

\section{Thermal, hydrological and optical background conditions}

Clear cyclical seasonal changes in water temperature and thermal stratification were evident in both lakes (Fig. 3a), with some additional inter-annual variability in thermal conditions understandably associated with hydrology (Fig. 3b). Between-lake

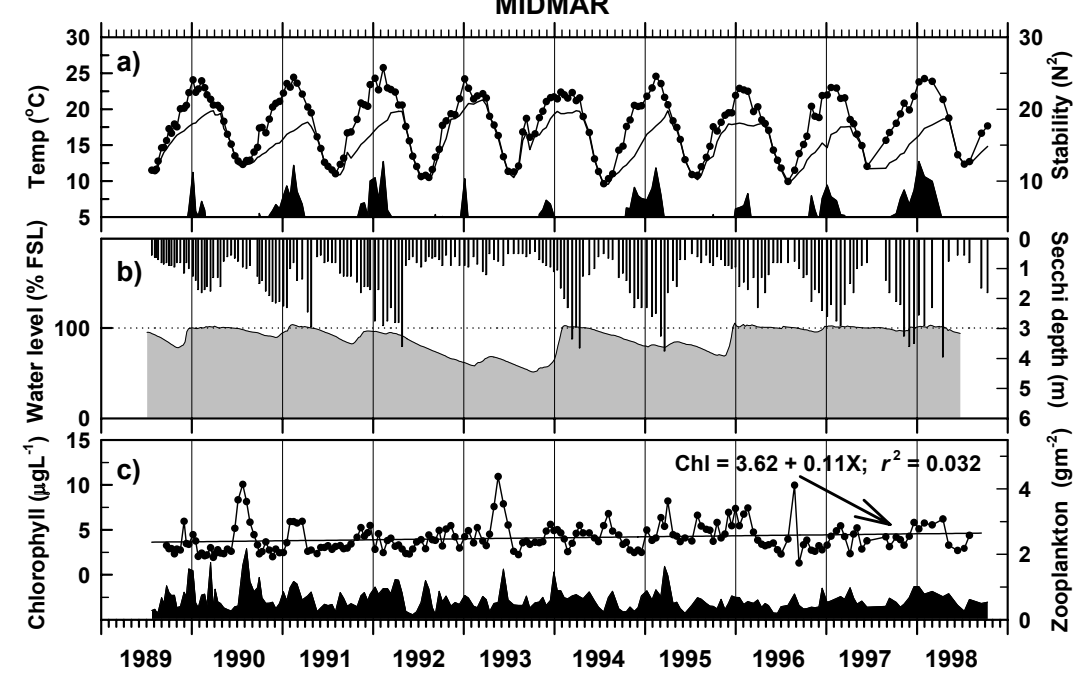

ALBERT FALLS

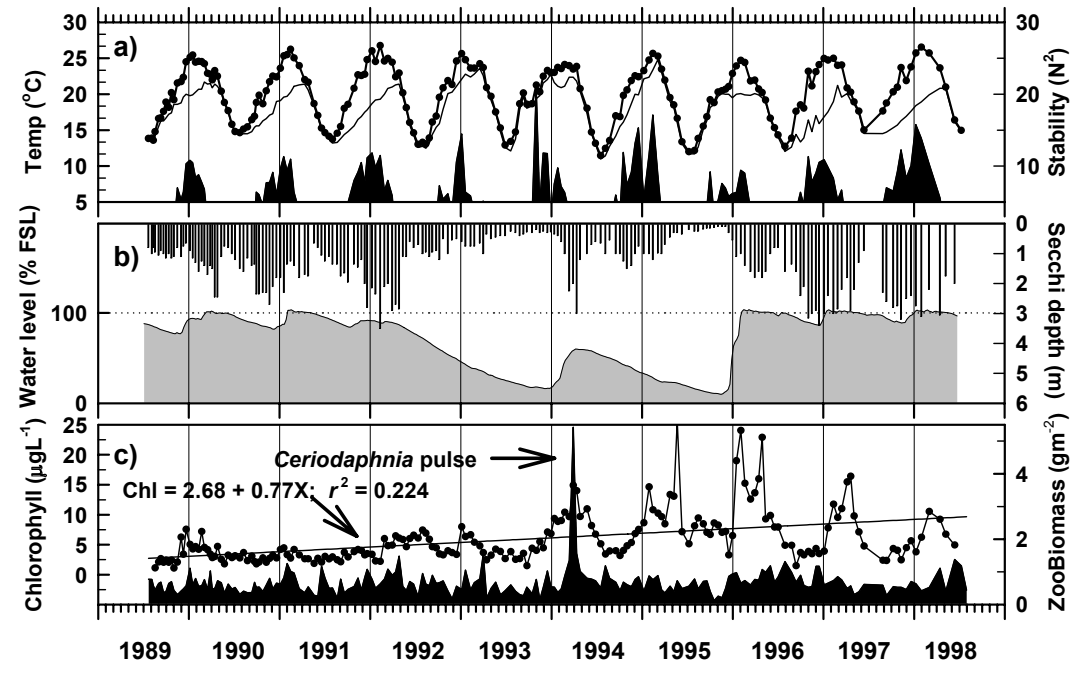

Figure 3

Synopsis of limnological conditions in Midmar and Albert Falls (upper and lower panels respectively) during the study period. a) Temporal changes in upper (1-5m mean) and bottom temperatures, with estimates of physical stability $\left(\left(N^{2}\right.\right.$, shaded plot); b) Secchi depth transparency in relation to water level; c) Chlorophyll concentrations (shaded plot, with overall temporal trend plotted as a linear regression, where $X$ is years from start of study) and estimated zooplankton biomass. 


\begin{tabular}{|c|c|c|c|}
\hline \multicolumn{4}{|c|}{$\begin{array}{c}\text { TABLE } 3 \\
\text { Comparative mean PAR coefficients in } \\
\text { each reservoir during this study, and } \\
\text { comparative spectral coefficients on an } \\
\text { occasion of identical PAR values }\end{array}$} \\
\hline & & Midmar & Albert Falls \\
\hline \multirow{5}{*}{$\begin{array}{l}K_{\text {d PAR }} \\
\text { Sept } 1989 \\
\text { to } \\
\text { July } 1998\end{array}$} & Mean & 1.383 & 1.954 \\
\hline & Median & 1.341 & 1.345 \\
\hline & Max & 2.715 & 13.253 \\
\hline & Min & 0.464 & 0.517 \\
\hline & $\mathrm{n}$ & 192 & 193 \\
\hline$K_{\mathrm{d} \mathrm{RED}}$ & \multirow{4}{*}{$\begin{array}{l}4 \text { Sept } \\
1991\end{array}$} & 1.25 & 1.10 \\
\hline$K_{\text {d GREEN }}$ & & 1.53 & 1.29 \\
\hline$K_{\mathrm{d} \text { BLUE }}$ & & 2.72 & 2.07 \\
\hline$K_{\mathrm{dPAR}}$ & & 1.32 & 1.32 \\
\hline
\end{tabular}

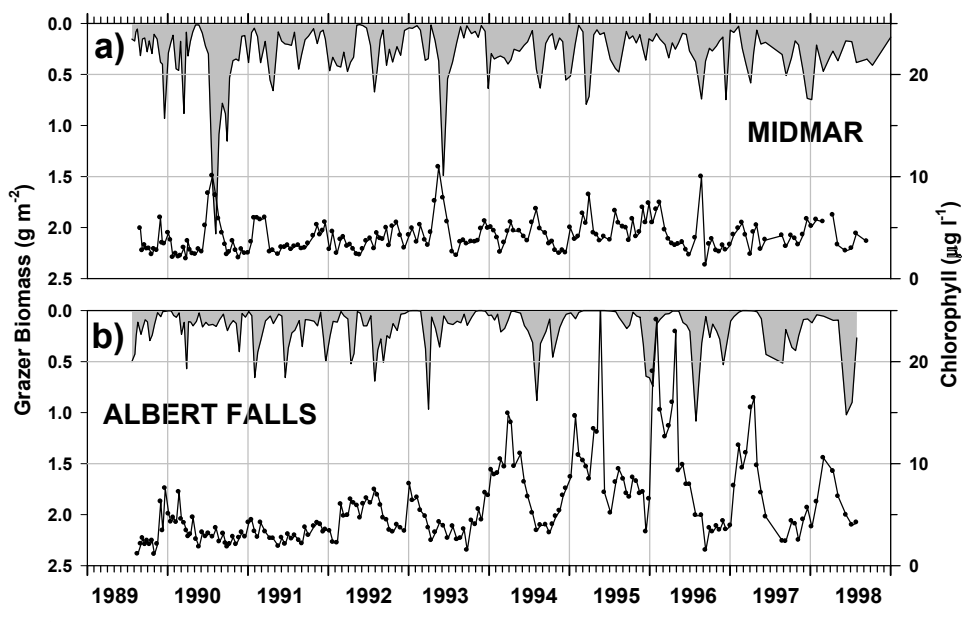

Variations in PAR attenuation coefficients were equally broad (summary values in Table 3 ). On various occasions that spectral characteristics were determined, red light was the most penetrating component in both reservoirs, followed by green and blue light. Spectral characteristics for MID during this study were comparable to those previously reported (Breen, 1983); no previous values for ALF are known. Deep penetration of red wavelengths is widely associated with the light-scattering effects of suspended clays (Kirk, 1983). The fact that red was also the most penetrating wavelength in this downstream reservoir was accordingly surprising, given MID's potential function as an upstream sedimentation basin. Rather, it indicates that sedimentation may instead be overwhelmed by re-suspension, a feature that likely pertained during the 'low water phase' conditions that occurred during much of the study (Fig. 3b).

\section{Autotroph temporal dynamics - chlorophyll proxy}

Changes in chlorophyll content in relation to selected abiotic factors, and potential grazer biomass, are reflected in Fig. 3c. While no clear long-term trend in chlorophyll content was evident in MID (Fig. 3c), linear regression analysis of mean annual values yielded an overall slight, but very significant positive slope with time (X, years from mid 1987): Chl $a=3.62+0.11 \mathrm{X} ; r^{2}=$ $0.032, p=0.012$ ). In contrast, a more distinct long-term increase occurred in ALF, for which a corresponding regression of Chl $a$ $=2.68+0.77 \mathrm{X} ; r^{2}=0.224, \mathrm{p}<0.0001$ was obtained (Fig. $3 \mathrm{c}$ ). Chlorophyll values reached eutrophic range levels during the middle of the study period. Intra-annual variation was evident in both lakes; in MID, chlorophyll peaks commonly occurred in mid-winter but timing of maxima showed rather weak periodicity in ALF.

Several peaks in zooplankton biomass roughly coincided with chlorophyll peaks, especially in MID in winter (Fig. 3c); closer scrutiny hints at a general lag of one sampling interval between these peaks (but see below). Pearson's direct and Spearman's rank correlations between chlorophyll and grazer zooplankton biomass were highly significant $(\mathrm{p} \leq 0.001)$ overall in both lakes, with respective $r^{2}$ and $r_{\mathrm{s}}$ values of 0.318 and 0.288 for MID, and 0.243 and 0.264 for ALF. Correlations with Daphnia biomass alone were inconsistent for $\operatorname{MID}\left(0.301\right.$ and $\left.0.095^{\mathrm{ns}}\right)$ but were both strongly negative for ALF (-0.207 and -0.369). Lagged correlations between total grazer or Daphnia biomass and

chlorophyll level on the preceding sampling date were variously stronger or weaker than, but generally comparable to their unlagged equivalents (corresponding values of $0.355,0.286,0.176$ and 0.273 in the above sequence). However, very clear evidence of the regulation of algae by zooplankton grazers was manifest in ALB, where maximal chlorophyll values corresponded with severe reductions or disappearance of Daphnia in particular (Fig. 4), as well as the strong overall negative correlations.

\section{Temporal dynamics - taxonomic account}

General - A rather low total of nearly 60 different taxa were encountered during the study, with an overall diversity ranking of Chlorophytes $>$ Bacillariophytes $>$ Cyanophytes $>$ Pyrrophytes. Roughly $25 \%$ of these taxa are excluded from further consideration by the inclusion index threshold described above. Distinctive taxa within a genus were distinguished by alphabetic labels. Where available, (tentative) species identifications are provided below at first mention.

Based on the intermediate disturbance hypothesis, which partly underpinned the research direction (Hart, 1992) of which the present account is a product, rather more taxa would be anticipated (Padisák et al., 1993; Reynolds, 1995). The relatively low number of taxa recorded may be partly attributable to inadequate distinction among morphologically closely similar taxa within a non-specialist study.

Diatoms and desmids - These groups are considered jointly since desmids function as "green diatoms" (Reynolds, 2005) Figures 5 and 6 show the temporal variability of dominant taxa in this category in Midmar and Albert Falls, respectively. 

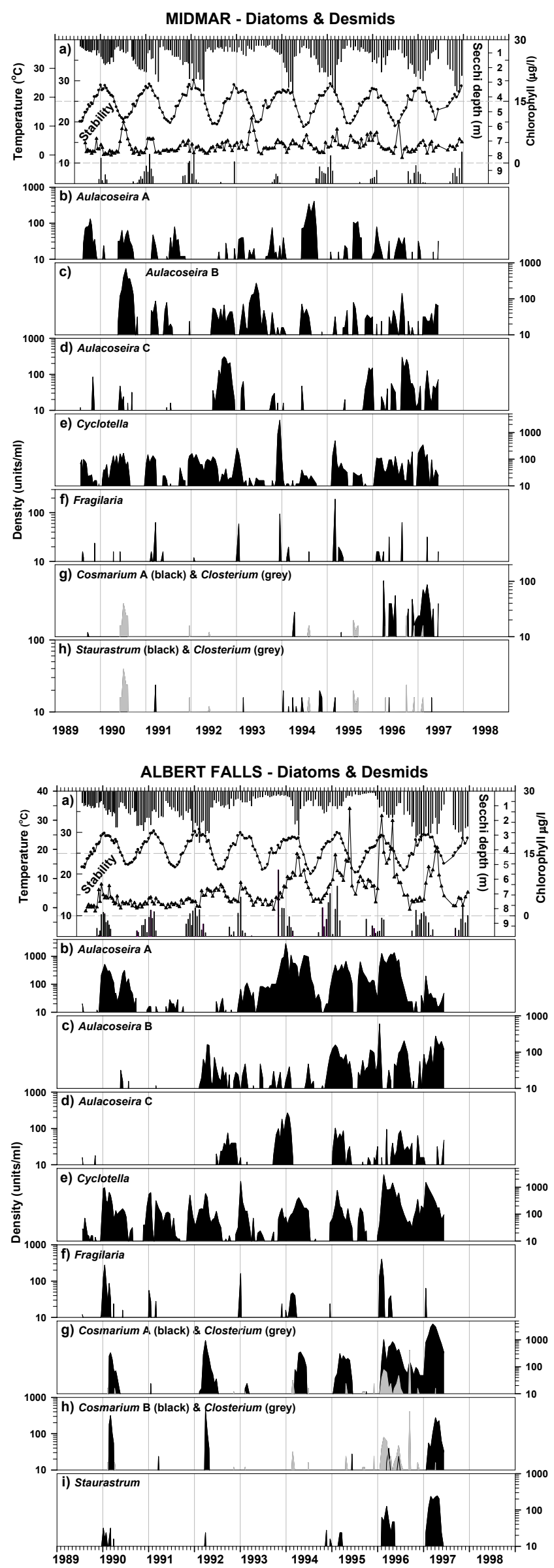

Aulacoseira was the dominant diatom in both lakes; two species $(\mathrm{A}=$ A. granulata and $\mathrm{B}=A$. granulata var. angustissima $)$ were present virtually through the entire study (Figs. 5b, 5c; 6b, 6c), while a third species $(\mathrm{C}=$ Aulacoseira $\mathrm{sp}$.) rose in prominence in MID from 1992 (Fig. 5d), and appeared almost concurrently in ALF (Fig. 6d). ) Taxa in the genus showed extended (but not continuous) seasonal occurrences in ALF, but were generally more 'seasonal' in MID. Major annual peaks of Aulacoseira species $\mathrm{A}$ and $\mathrm{B}$ were quite consistently mid-winter events in MID (Figs. 5b, 5c), but less regular in ALF, where peaks variously occurred both in mid-summer and mid-winter in different years (Figs. 6b, 6c), with some indications of bimodal occurrences. Considerable between-year variability in abundance was evident, especially for Aulacoseira A; this diatom was sparse in ALF in 1991 and 1992, but increased radically in 1993 as water clarity dropped with the rise in suspended sediments corresponding with declining water levels (Fig. 3b), and thereafter tended to remain more abundant. Significant $(\mathrm{p}<$ 0.001) inverse correlations of Aulacoseira A density and Secchi depth transparency were evident both in MID $\left(r_{\mathrm{s}}=-0.293\right)$ and ALF $\left(r_{\mathrm{s}}=-0.386\right)$. Peak annual densities of both Aulacoseira species A and B also varied considerably in both lakes. Based on correlation analysis, Aulacoseira A was inferred to be the major contributor to chlorophyll concentration in ALF $(r=0.499$; $\left.r_{\mathrm{s}}=0.577 ; \mathrm{p}<0.001\right)$, but less strongly in MID $(r=0.099, \mathrm{~ns}$; $\left.r_{\mathrm{s}}=0.212 ; \mathrm{p}=0.004\right)$.

Cyclotella was seasonally the most persistent member of the diatom/desmid assemblage in both lakes, but reached consistently higher densities in ALF than MID (Figs. 5e, 6e). This diatom commonly peaked in late summer/autumn, often after a fairly consistent mid-summer decline from an irregular spring/ early summer development. Although relatively sparse, Fragilaria peaked fairly consistently in mid-summer (Figs. 5f, 6f).

Several desmids - Cosmarium, Staurastrum and Closterium - occurred in significant numbers in some years, reaching consistently higher densities in ALF than in MID (Figs. 5g, 5h; 6g to 6i). Species of Cosmarium (species A in MID, and both A and B in ALF) and Staurastrum appeared inconsistently from year to year, but showed quite consistent brief late- summer developments in the years they were present. Staurastrum was much sparser in MID than in ALF, where its annual prominence increased in later years of the study (as too did Cosmarium A in both lakes). Closterium showed sparse autumn/winter peaks in both lakes, and as with Cosmarium A and Stuarastrum, also increased in ALF in later years.

Cryptomonas and non-desmid chlorophytes - Figures 7 and 8 illustrate the seasonal and inter-annual variations in this Chryptophyte and the non-desmid members of the green algal assemblage in MID and ALF respectively. Cryptomonas was clearly the taxon with the most extended seasonal presence in both lakes, and was substantially more abundant in ALF than MID (Figs. 7b and 8b). Two species of Crucigenea (spp. A and

Temporal changes in composition and abundance of specified taxa in relation to changes in selected abiotic and biotic variables:

Figure 5 (top left)

Bacillariophytes and desmid Chlorophytes (mostly ruderal taxa) in Midmar.

Figure 6 (bottom left)

Bacillariophytes and desmid Chlorophytes (mostly ruderal taxa) in Albert Falls. 
B) and Closteriopsis assumed broadly comparable second-rank co-dominance in both lakes, although the density of all these three taxa generally tended to be marginally higher in ALF than in MID. No clear recurrent seasonal pattern was evident among these taxa, although all reached mid-year (winter) peaks in both lakes in certain years, and were often absent or present at greatly depressed densities in mid-summer. Seven additional taxa - Scenedesmus, Schröderia, Tetraedron, Oocystis, Ankistrodesmus, Coelastrum and Trachelomonas - contributed to this broad taxonomic assemblage in low densities. Several of these taxa increased in abundance in ALF in the latter half of the study; this feature was most clearly manifest in Scenedesmus, Tetraedron and Ankistrodesmus (Figs. 8f, 8g and 8h). A broadly parallel increase in MID was evident for Ankistrodesmus, which only reached significant densities in MID in the 1996/97 year (Fig. 7h). Of the four remaining taxa, Trachelomonas was seasonally most persistent, and more abundant in ALF than MID. An unresolved paradox is the absence of Chlorella in this record: Graham et al. (1998) identified it as an overwhelming dominant in both lakes.

Cyanophytes and Pyrrophytes - Temporal changes in cyanophytes and pyrrophytes in MID and ALF are shown in Figs. 9 and 10, respectively. Substantial increases in abundance and seasonal duration in the later years of study were evident in both lakes for several cyanophytes - especially Microcystis (= M. aeruginosa) and Anabaena species A and C. Brief and seasonally inconsistent peaks of Nodularia were observed in ALF; in contrast, this taxon was sporadic in MID (Fig. 9g). Surprisingly, several of the more prominent taxa showed substantial mid-summer declines and even effectively disappeared in some years although little consistency was evident between taxa and lakes - apart from the virtual absence of all taxa in this assemblage in both lakes at the end of 1996. Pyrrophytes barely featured in MID, in which only Peridinium reached the inclusion threshold in the final years of study (Fig. 9h). In ALF, Ceratium was the dominant member of this group but was absent or scarce in the initial years of the study. However, in the years when representation of this group was tangible, both taxa were seasonally restricted to late summer, except during 1992, when they featured in winter (Fig. 10i).

\section{Temporal dynamics - functional categories}

Ruderal taxa - The prime disturbance factor selecting for ruderal strategist taxa is that of vertical mixing. On this basis, ruderal taxa abundance should relate inversely to stability. While broadly true for MID (Fig. 5), some radical departures from this expectation were evident in ALF (Fig. 6), where Aulacoseira A for example, reached its peak abundance in mid-summer of 1993/94, and was common later in summer in several years, but conversely declined to mid-year insignificance in other years (Fig. 6b). Rank correlations between abundance and stability

Temporal changes in composition and abundance of specified taxa in relation to changes in selected abiotic and biotic variables:

Figure 7 (top right)

Cryptomonas/Cryptophytes and non-desmid Chlorophytes (mostly colonist taxa) in Midmar.

Figure 8 (bottom right)

Cryptomonas/Cryptophytes and non-desmid Chlorophytes (mostly colonist taxa) in Albert Falls.
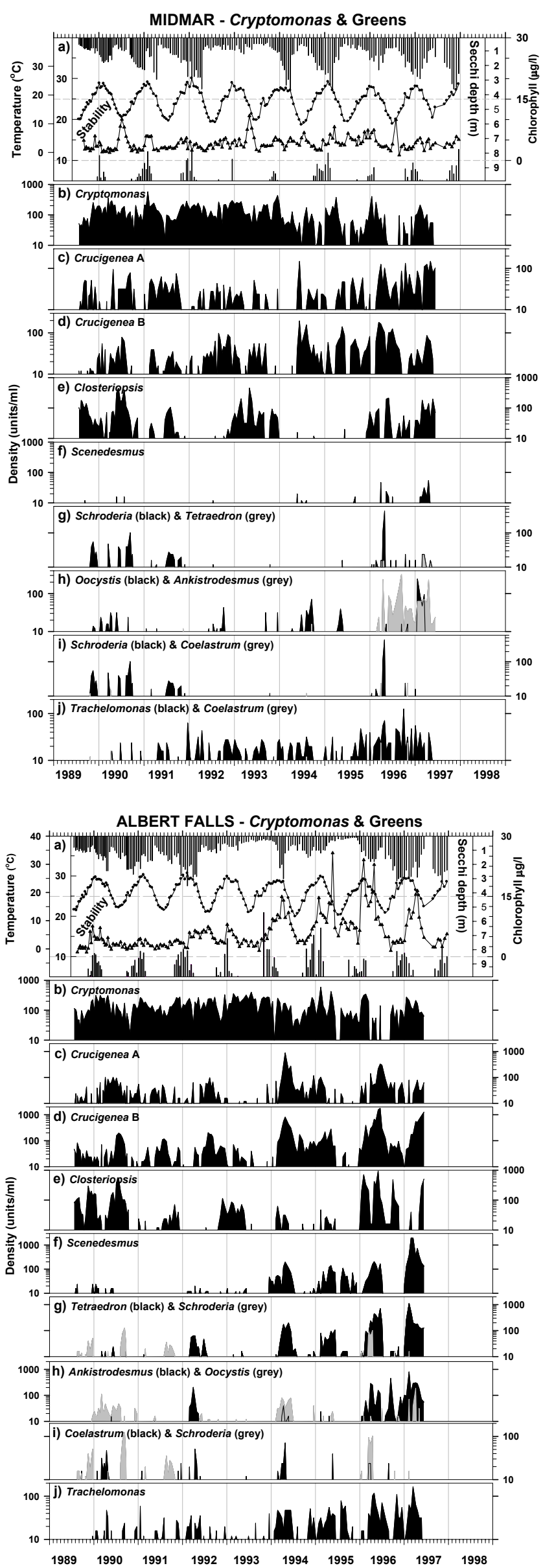

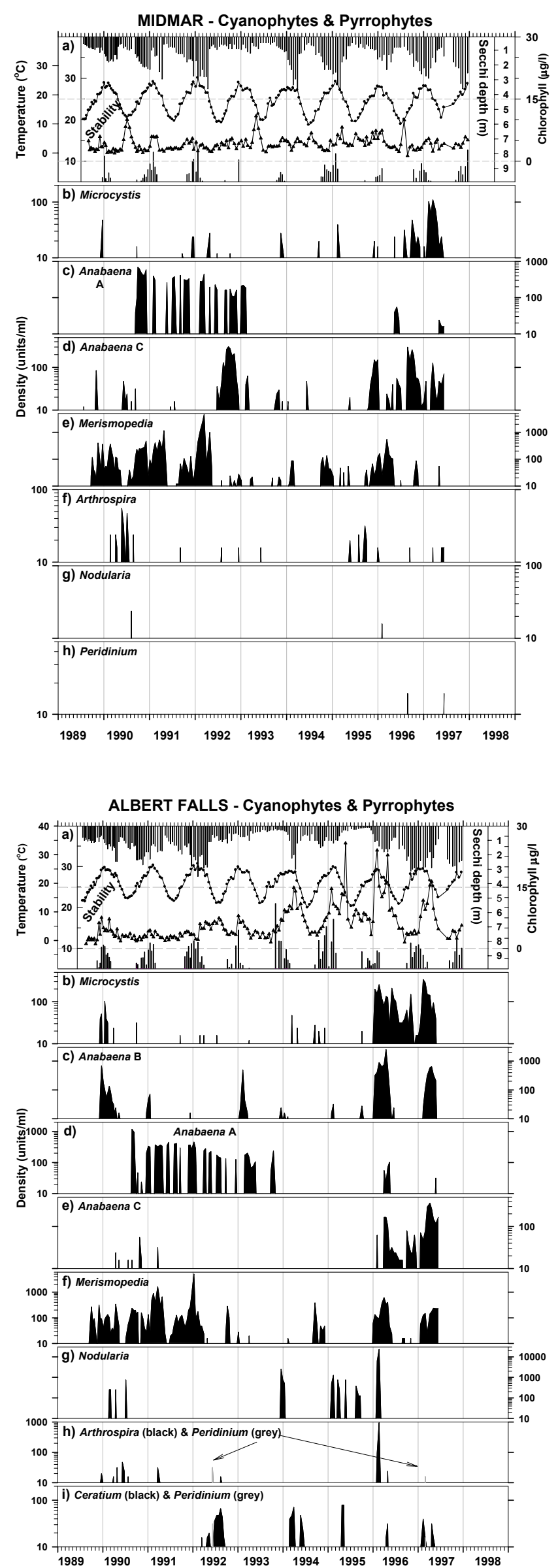

reflect this variability in response (Table 4). Correlations were negative for six of the nine taxa in MID, but for only three taxa in ALF, but were significant for only one taxon in each reservoir (Table 4). This pattern was maintained even when confounding influences of change in water depth were controlled for using partial correlation analysis.

Competitive/colonist taxa - The abundance of most C-strategist taxa correlated negatively with stability in both reservoirs (9 of 11 taxa), significantly so for 4 taxa in MID, and 3 taxa in ALF (Table 4). All significant correlations were directionally consistent for given taxa in both reservoirs; the only taxon that was significantly positively correlated to stability was Cryptomonas - a motile flagellate. Although somewhat unexpected, the predominance of negative correlations with stability in this functional subset is consistent with its 'colonist' nature - hydraulic disturbances that reset autogenic succession effectively create the 'gap' for colonist occupancy.

Stress-tolerant taxa - The positive correlations expected between abundance and stability for taxa in this assemblage were not unambiguously realised, although the only significant correlations ( 3 in MID, 1 in ALF) were correctly positive (Table 4). Several other taxa showed directionally opposite (but insignificant) correlations in the two reservoirs (Table 4).

\section{Hypothesis interrogation}

\section{Influences of mixing and stratification on phyto- plankton}

The numerical proportional contributions of ruderal, colonist and stress-tolerant taxa over the entire study period respectively averaged $0.361,0.328$ and 0.311 in MID and 0.449, 0.292 and 0.258 in ALF. These relative proportions were not significantly different overall in MID (ANOVA; $F=2.2, \mathrm{p}=0.108$ ), but differences were highly significant in ALF $(F=32.185, \mathrm{p}<0.001)$. Based on differences in stratification intensity between the reservoirs, initial predictions that a) the proportional dominance of ruderal taxa should be greater in MID than in ALF, while b) stress tolerant taxa should be more dominant in ALF than MID, were not realised overall. Comparative analyses of high $(>50 \%$ FSL) and low $(<50 \%$ FSL $)$ water-level data confirmed that the postulated increase in proportion of ruderal taxa (prediction $\mathrm{c}$ ) was highly significant ( $\mathrm{p}<0.001$ both by ANOVA and $t$-tests) in both lakes: from 0.362 to 0.562 in MID, and from 0.366 to 0.474 in ALF, suggesting a controlling influence of hydrological variation as a major determinant of community structure. Predictability of algal dynamics requires the careful consideration and "factoring in" of such hydrological variability, as it is clearly an over-riding regional influence in reservoir functioning.

The extended presence of numerically strong populations of Cryptomonas in both lakes is especially notable. This feature is entirely in keeping with its status as a C-S-R "generalist";

Temporal changes in composition and abundance of specified taxa in relation to changes in selected abiotic and biotic variables:

Figure 9 (top left)

Cyanophytes and Pyrrophytes (mostly stress-tolerant taxa) in Midmar.

Figure 10 (bottom left)

Cyanophytes and Pyrrophytes (mostly stress-tolerant taxa) in Albert Falls. 
Cryptomonas virtually ruled the worlds of the two study reservoirs, affirming its position in successfully blending all three strategies (Reynolds, 2005). Its prolonged presence is in keeping with the very environmentally dynamic nature of these reservoirs, further emphasising the closing statement of the preceding paragraph.

\section{Inferred grazer impacts on phy- toplankton}

The relationship between chlorophyll (i.e. algal biomass) and grazing zooplankton biomass was surprisingly discordant in the two reservoirs. A very significant negative relationship was apparent in ALF (Fig. 4d), in keeping with direct grazer control logically anticipated from typical general predator-prey interactions. The equally strong but direct relationship in MID (Fig. 4c) conversely implied that phytoplankton was stimulated rather than regulated by grazer activity in this upstream reservoir. The direct relationship in MID may be partly attributable to the dominance of large ruderal elements, especially of large filaments of Aulacoseira, that exceed the size range of easily ingestible foods for suspension feeding cladocerans. Furthermore, the negative consequences of suspended sediments on cladoceran suspensionfeeding efficiency (e.g. Hart, 1988) are predictably expected to be greater in the sediment-richer waters (mirrored in lower water transparency - Fig. 3b) of this upstream reservoir. The 'headwater' location of MID further renders it nutrient-poorer than ALF, a speculated consequence of which is that nutrient recycling by grazers may provide a greater stimulation to phytoplankton growth in MID than in ALF (although this speculation is contradicted by the significantly higher average Daphnia biomass $\left(0.293\right.$ vs. $0.176 \mathrm{~g} \cdot \mathrm{m}^{-2}$; $\mathrm{p}<0.001, \mathrm{n}=199$, paired $t$-test: although total cladoceran and total grazer biomass did not differ significantly), and implied higher resource repletion in MID. Regardless of causality, however, this fundamental contrast importantly emphasises the illusion of ecological generality (Dunham and Beaupre, 1998; Morin, 1998), and the corollary requirement for systems-specific analyses to unravel systemspecific response.

Differential influences of grazing on specified categories of phytoplankton were also variable and generally inconsistent between the lakes. In MID, the proportional abundance of C, S and $\mathrm{R}$ taxa on given sampling dates was consistent with the initial prediction that small autotrophs (colonist taxa) would relate inversely while large (stress-tolerant taxa) would relate directly or not at all to grazer biomass, whereas parallel evidence in ALF
TABLE 4

\section{Spearman rank correlations between abundance levels of specified algal taxa and water column stability in Midmar and Albert Falls. Significant correlations are highlighted.}

\begin{tabular}{|c|c|c|c|c|c|c|}
\hline \multirow[t]{2}{*}{ Stability vs. } & \multicolumn{3}{|c|}{ Midmar } & \multicolumn{3}{|c|}{ Albert Falls } \\
\hline & $r_{\mathrm{s}}$ & p & $\mathbf{n}$ & $r_{\mathrm{s}}$ & $\mathbf{p}$ & $\mathbf{n}$ \\
\hline Aulacoseira sp. A & -0.138 & 0.115 & 131 & 0.031 & 0.698 & 159 \\
\hline Aulacoseira sp. B & -0.241 & 0.007 & 125 & -0.017 & 0.854 & 122 \\
\hline Aulacoseira sp. C & 0.083 & 0.434 & 91 & 0.091 & 0.412 & 84 \\
\hline Aulacoseira (all spp.) & -0.223 & 0.004 & 163 & 0.025 & 0.740 & 173 \\
\hline Fragilaria & -0.035 & 0.769 & 72 & 0.383 & 0.002 & 60 \\
\hline Cyclotella & -0.001 & 0.988 & 163 & 0.161 & 0.037 & 168 \\
\hline All diatoms & -0.145 & 0.051 & 180 & 0.043 & 0.571 & 174 \\
\hline Cosmarium sp. A & -0.089 & 0.618 & 34 & -0.192 & 0.088 & 80 \\
\hline Cosmarium sp. B & 0.894 & 0.104 & 4 & 0.134 & 0.479 & 30 \\
\hline Staurastrum & 0.135 & 0.414 & 39 & 0.044 & 0.741 & 58 \\
\hline Closterium & -0.193 & 0.099 & 74 & -0.208 & 0.125 & 56 \\
\hline All desmids & -0.073 & 0.440 & 114 & -0.171 & 0.084 & 103 \\
\hline All ruderals & -0.167 & 0.023 & 184 & 0.107 & .149 & 183 \\
\hline Anabaena sp. A & 0.506 & 0.001 & 40 & -0.081 & 0.581 & 49 \\
\hline Anabaena sp. B & -0.610 & 0.061 & 10 & 0.228 & 0.046 & 77 \\
\hline Anabaena sp. C & -0.278 & 0.137 & 30 & 0.176 & 0.276 & 40 \\
\hline Anabaena (all spp.) & 0.184 & 0.138 & 66 & 0.040 & 0.660 & 125 \\
\hline Microcystis & 0.078 & 0.538 & 65 & -0.100 & 0.395 & 75 \\
\hline Merismopedia & 0.327 & 0.000 & 123 & 0.137 & 0.156 & 108 \\
\hline Nodularia & 0.203 & 0.700 & 6 & 0.344 & 0.176 & 17 \\
\hline All cyanophytes & 0.132 & 0.100 & 156 & 0.195 & 0.015 & 165 \\
\hline Ceratium & $\mathrm{n} / \mathrm{a}$ & $\mathrm{n} / \mathrm{a}$ & $\mathrm{n} / \mathrm{a}$ & -0.094 & 0.601 & 33 \\
\hline Peridinium & -0.414 & 0.414 & 6 & -0.064 & 0.843 & 12 \\
\hline Trachelomonas & -0.185 & 0.029 & 138 & -0.046 & 0.598 & 136 \\
\hline All stress tolerators & 0.302 & 0.000 & 184 & 0.182 & 0.014 & 183 \\
\hline Cryptomonas & 0.238 & 0.002 & 176 & 0.223 & 0.003 & 178 \\
\hline Crucigenea A & -0.240 & 0.002 & 158 & -0.248 & 0.002 & 150 \\
\hline Crucigenea B & -0.248 & 0.002 & 157 & -0.361 & 0.000 & 160 \\
\hline Tetraëdron & -0.283 & 0.077 & 40 & -0.108 & 0.279 & 102 \\
\hline Scenedesmus & -0.193 & 0.143 & 59 & -0.006 & 0.948 & 123 \\
\hline Closteriopsis & -0.309 & 0.000 & 132 & -0.187 & 0.042 & 119 \\
\hline Arthrospira & -0.088 & 0.562 & 46 & -0.134 & 0.480 & 30 \\
\hline Ankistrodesmus & 0.046 & 0.727 & 59 & -0.029 & 0.825 & 62 \\
\hline Oocystis & -0.036 & 0.736 & 92 & -0.051 & 0.652 & 80 \\
\hline Schröderia & -0.120 & 0.421 & 47 & 0.047 & 0.784 & 37 \\
\hline Coelastrum & -0.043 & 0.798 & 38 & -0.080 & 0.588 & 48 \\
\hline All colonists & -0.395 & 0.000 & 184 & -0.252 & 0.001 & 183 \\
\hline
\end{tabular}

was not unequivocal. Relationships between $\mathrm{C}$ taxa and total grazer biomass, cladoceran biomass, and Daphnia biomass were all significant, and negative (as predicted) for MID $(r=-0.249 * *$, $-0.177^{*}$ and $-0.143 *$ respectively), but insignificant (and positive) for ALF (in contrast to the opposite pattern shown for total grazer biomass and chlorophyll). Corresponding values for $\mathrm{S}$ taxa were $0.143^{*}, 0.073$ and 0.055 for MID, and $-0.063,-0.030$ and 0.132 for ALF. Only the (just) significant value is consistent with the initial prediction. Somewhat unexpectedly, Daphnia biomass and ruderal taxa in ALF demonstrated the strongest relationship overall $\left(-0.207^{* *}\right)$. While no relationships between any categories of grazer biomass and absolute (rather than relative) 


\begin{tabular}{|c|c|c|c|c|c|c|}
\hline \multicolumn{7}{|c|}{$\begin{array}{l}\text { TABLE } 5 \\
\text { Empirical tests of initial predictions (see pages } 3-4 ; \mathrm{Y}=\text { support; } \mathrm{N}=\text { contradiction) for each reservoir during } \\
\text { the entire study, and comparative annual high- and low-water level phases. Values shown variously represent } \\
\text { mean proportional values or regression coefficients. Values in shaded cells reflect differences in the predicted } \\
\text { direction; significant differences ( } \mathrm{p}<0.05 \text { by ANOVA, linear regression or } t \text {-test) are emboldened; bold values } \\
\text { reflect significant differences in the predicted direction (shaded blocks) or contrary direction (un-shaded). }\end{array}$} \\
\hline \multirow[t]{3}{*}{ Predictions: } & \multicolumn{6}{|c|}{ Empirical observations } \\
\hline & \multicolumn{2}{|c|}{$\begin{array}{c}\text { Overall } \\
\text { Aug } 1989 \text { to } \\
\text { June } 1997\end{array}$} & \multicolumn{2}{|c|}{$\begin{array}{c}\text { High-water } \\
\text { Jan to Dec } \\
1990\end{array}$} & \multicolumn{2}{|c|}{$\begin{array}{c}\text { Low-water } \\
\text { Jan to Dec } \\
1993 \\
\end{array}$} \\
\hline & MID & ALF & MID & ALF & MID & ALF \\
\hline \multirow{2}{*}{$\begin{array}{l}\text { a) ' } R \text { ' taxa proportionately commoner in } \\
\text { MID than ALF }\end{array}$} & 0.360 & 0.449 & 0.277 & 0.379 & 0.462 & 0.629 \\
\hline & \multicolumn{2}{|c|}{$\mathbf{N}$} & \multicolumn{2}{|c|}{$\mathrm{N}$} & \multicolumn{2}{|c|}{$\mathbf{N}$} \\
\hline \multirow{2}{*}{$\begin{array}{l}\text { b) 'S' taxa proportionately commoner in } \\
\text { ALF than MID }\end{array}$} & 0.258 & 0.311 & 0.419 & 0.317 & 0.152 & 0.205 \\
\hline & \multicolumn{2}{|c|}{$\mathrm{Y}$} & \multicolumn{2}{|c|}{$\mathrm{N}$} & \multicolumn{2}{|c|}{$\mathrm{Y}$} \\
\hline \multirow[t]{2}{*}{$\begin{array}{l}\text { c) ' } R \text { ' taxa proportionately commoner at } \\
\text { low than high water level }\end{array}$} & $\begin{array}{c}0.474 \\
0.331 *\end{array}$ & $\begin{array}{c}0.562 \\
0.366^{*}\end{array}$ & 0.277 & 0.379 & 0.462 & 0.629 \\
\hline & $\mathbf{Y}$ & $\mathbf{Y}$ & $\mathbf{Y}$ & $\mathbf{Y}$ & $\mathbf{Y}$ & $\mathbf{Y}$ \\
\hline \multirow{4}{*}{$\begin{array}{l}\text { d) 'C' taxa vary inversely with grazers } \\
\text { 'S' taxa vary directly or not at all with } \\
\text { grazers }\end{array}$} & -0.249 & 0.109 & -0.246 & -0.429 & -0.283 & 0.417 \\
\hline & $\mathrm{Y}$ & $\mathrm{N}$ & $\mathrm{Y}$ & $\mathrm{Y}$ & $\mathrm{Y}$ & $\mathbf{N}$ \\
\hline & 0.143 & 0.132 & -0.096 & -0.183 & -0.120 & 0.566 \\
\hline & $\mathrm{Y}$ & $\mathrm{Y}$ & $\mathrm{N}$ & $\mathrm{N}$ & $\mathrm{N}$ & $\mathbf{Y}$ \\
\hline \multirow{2}{*}{$\begin{array}{l}\text { e) proportionately more 'S' taxa: } \\
\text { i) in MID }\end{array}$} & 0.258 & 0.311 & 0.419 & 0.317 & 0.152 & 0.205 \\
\hline & \multicolumn{2}{|c|}{$\mathrm{N}$} & \multicolumn{2}{|c|}{$\mathrm{N}$} & \multicolumn{2}{|c|}{$\mathrm{N}$} \\
\hline ii) in ALF & \multicolumn{2}{|c|}{$\mathrm{Y}$} & \multicolumn{2}{|c|}{$\mathrm{Y}$} & \multicolumn{2}{|c|}{$\mathrm{Y}$} \\
\hline iii) comparable in both lakes & \multicolumn{2}{|c|}{$\mathbf{Y}$} & \multicolumn{2}{|c|}{$\mathbf{Y}$} & \multicolumn{2}{|c|}{$Y$} \\
\hline No. predictions upheld (of 16): & \multicolumn{2}{|c|}{9} & \multicolumn{2}{|c|}{6} & \multicolumn{2}{|c|}{6} \\
\hline Correct direction, but $\mathrm{p}>0.05$ & \multicolumn{2}{|c|}{6} & \multicolumn{2}{|c|}{4} & \multicolumn{2}{|c|}{6} \\
\hline Correct direction; $\mathrm{p}<0.05$ & \multicolumn{2}{|c|}{3} & \multicolumn{2}{|c|}{2} & \multicolumn{2}{|c|}{3} \\
\hline Significantly contradictory & & & & & & \\
\hline
\end{tabular}

abundance of C, S and R taxa were significant in MID, Daphnia biomass correlated inversely both with $\mathrm{C}$ and $\mathrm{R}$ taxa densities in ALF $\left(-0.173^{*},-0.271^{* *}\right)$. Correlations between total grazer or cladoceran biomass and autotroph density did not approach significance.

\section{Influences of trophic status on phytoplankton composition}

Based on the premises of prediction e) (in Table 5), the greater proportional prominence of S taxa observed in MID than ALF ( 0.311 vs. $0.258 ; \mathrm{p}=0.017$ - paired $t$-test) implies that extrinsic nutrient level constraints may exceed the intrinsic limitation imposed by stratification. Nutrient concentrations for MID and ALF reported by Graham et al. (1998) indicate comparable multi-annual mean levels $\left(\mu \mathrm{g} \cdot \ell^{-1}\right)$ of TP $(24.1,28.1)$ and $\mathrm{TN}_{\text {inorganic }}(327,358)$, with TN:TP ratios of 20.9 and 24.3 in MID and ALF respectively between (perhaps) 1990 and 1994. However, inter-annual changes and variability in stratification intensity within the reservoirs confound attempts to distinguish response causality within and between these water bodies during the present study. Alternatively, the limited degree of difference observed between the reservoirs may imply that causality cannot be ascribed independently to intrinsic nor extrinsic influences, but rather reflects their interactive influences, with blurred or confounded effects. Without contemporaneous chemical evidence regarding comparative nutrient concentrations, further deliberation of this point is conjectural.

\section{Predictability of annual periodicity}

Meaningful conclusions about the existence or otherwise of cyclical seasonal repetitions of phytoplankton dynamics in reservoirsunderSouth African conditions are difficult to attempt on the basis of presently limited empirical data, which is especially poignant to the notional illusion of ecological generality (Dunham and Beaupre, 1998; Morin, 1998). Available evidence does, however, suggest that inter-annual variability within single systems (Pieterse and Röhrbeck, 1990; Pieterse and Janse van Vuuren, 1997; Zohary et al., 1996; this study) is considerable, as is the variability between systems. While the fundamental determinants of periodicity and successional change are universal (Reynolds, 1996; 1997; 1999), environmental variability inherent within and between reservoirs in this geographical region will delay, and may compromise attempts to define repeatable patterns of species abundance and assemblage associations comparable to those already synthesised for temperate waters (e.g. Reynolds, 1996; Kruk et al., 2002). The relatively low-frequency monitoring undertaken for SA reservoirs is also seriously out-of-step with the increasing trend towards short interval, even daily sampling, undertaken in temperate climes, that has stimulated the introduction of various automated/semi-automated analytical tools (Dubelaar et al., 2004; See et al., 2005) to replace conventional microscopy. 
While several of the initial predictions based on functional responses were not supported by evidence from the study overall, ecologically logical explanations are offered in the foregoing discussion to account for several of the disparities between expected and observed features. As these hinge largely on variability of the physical environment, greater concordance between expectations and observations might be expected over shorter time-frames. With this in mind, I selected shorter segments of the record to re-examine the initial predictions.

As such selection is difficult to justify objectively a priori, the calendar years of 1990 and 1993 were chosen somewhat arbitrarily as representative high- and low-water phase conditions, respectively (see Fig. 3), in order to minimise longer-term temporal variability.

Table 5 summarises the comparative 'validity' of each prediction for each lake over the entire study period with these two years of contrasting water level. While these results are not examined here in any further detail, Table 5 reflects little comparative improvement in prediction conformity between the annual and the overall data. Initial predictions may be incorrectly formulated, or unfounded. Nevertheless, the monitoring of autotroph dynamics using a functional approach is believed to remain as a useful adjunct to conventional taxonomic analysis, as demonstrated statistically using CANOCA by Kruk et al. (2002). In any event, prospects of predicting individual taxon responses remain daunting at best, if not impossible for all but a very limited number of taxa - such as Microcystis. Prospects of forecasting diatom periodicity at even generic level will demand much better documentary evidence than presently exists for reservoirs in South Africa. Conversely, forecasting the responses of functional groups (such as 'ruderals'), already approaches practicality. As indicated by Kruk et al. (2002), cross-phyletic and often overlapping selective influences confound the prediction of the phyletic composition of species - constraints that are explicitly tempered or removed by the functional approach.

Perhaps most importantly, this study identifies widely disparate effects of similar grazer assemblages on phytoplankton under broadly similar conditions in comparable lakes. Several attempts to characterise phytoplankton assemblages on the basis of trophic status in particular (e.g. Seip and Reynolds, 1995; Rojo et al., 2000) have not incorporated this influence, perhaps contributing to the apparent 'lack of pattern' among assemblages (Rojo et al., 2000). The influence has been recognised (Watson et al., 1997), but merits explicit incorporation in future attempts to identify congruent assemblage structure and species temporal dynamics.

\section{Acknowledgements}

This study was supported by successive grants from the Research Committee (URC) of the (then) University of Natal, and intermittently by the NRF. Particular thanks are due to Rei Hart for algal enumerations for most of the study period. A succession of conservancy officers (and particularly Matt Jackson at Midmar) at the Midmar and Albert Falls Nature Reserves (variously under jurisdiction of Natal Parks Board, Ezemvelo-KZN Wildlife and Msinsi Holdings) facilitated access to the reservoirs.

\section{References}

ALLANSON BR, HART RC, O'KEEFFE JH and ROBARTS, RD (1990) Inland Waters of South Africa. An Ecological Perspective. Kluwer Academic Publishers. Dordrecht. 458 pp.
ALLANSON BR and JACKSON PBN (eds.) (1983) Limnology and Fisheries Potential of Lake le Roux. South African National Scientific Programmes Report No 77. 182 pp.

ANDERSON DM, GLIBERT PM and BURKHOLDER JM (2002) Harmful algal blooms and eutrophication: Nutrient sources, composition, and consequences. Estuaries 25 704-726.

BAKER PD and HUMPAGE AR (1994) Toxicity associated with commonly occurring cyanobacteria in surface waters of the Murray-Darling basin, Australia. Aust. J. Mar. Freshwater Res. 45 773-786.

BARRELL R, BOYD P, COLE S, COLLEY A, GODFREE A, HOLT D and SARTORY D (2004) The Microbiology of Drinking Water Part 11 - Taste, Odour and Related Aesthetic Problems. Methods for the Examination of Waters and Associated Materials. Environment Agency, UK. 1-18.

BREEN CM (ed.) (1983) The Limnology of Lake Midmar. South African National Scientific Programmes Report No 78. 140 pp.

CHUTTER FM and ROSSOUW JN (1992) The Management of Phosphate Concentrations and Algae in Hartbeespoort Dam. WRC Report No 289/1/92. 37 pp.

DUBELAAR GBJ, GEERDERS PJF and JONKER RR (2004) High frequency monitoring reveals phytoplankton dynamics. J. Environ. Monit. 6 946-952.

DUNHAM AE and BEAUPRE SJ (1998) Ecological experiments. Scale, phenomenology, mechanism, and the illusion of generality. In: Resetarits WJ and Bernardo J (eds.) Experimental Ecology. Issues and Perspectives. Oxford University Press, Oxford. 27-49.

DEPARTMENT OF WATER AFFAIRS (1986) Management of the Water Resources of the Republic of South Africa. Department of Water Affairs, Pretoria. 457 pp.

FALCONER IR and HUMPAGE AR (1996) Tumour promotion by cyanobacterial toxins. Phycologia 35 74-79.

FALCONER IR and HUMPAGE AR (2001) Preliminary evidence for in vivo tumour initiation by oral administration of extracts of the bluegreen alga Cylindrospermopsis raciborskii containing the toxin cylindrospermopsin. Environ. Toxicol. 16 192-195.

FITZGERALD DJ, CUNLIFFE DA and BURCH MD (1999) Development of health alerts for cyanobacteria and related toxins in drinking water in South Australia. Environ. Toxicol. 14 203-209.

FRANK CAP and WOLF H-U (2002) Assessment of causes, frequency and toxicological significance of toxic cyanobacterial blooms in recreational waters in south-west Germany. Verh. Int. Ver. Limnol. 28 1775-1778.

GRAHAM PM, DICKENS CWS and MBOWA S (1998) Modelling the Water Quality in Impoundments within the Umgeni Water Operational Area and the Consequences for Potable Water Treatment Costs. WRC Report No 615/1/98. Water Research Commission, Pretoria, South Africa. 219 pp.

GRIME JP (1979) Plant Strategies and Vegetational Processes. Wiley Interscience, Chichester. 222 pp.

HALLEGRAEFF GM (1993) A review of harmful algal blooms and their apparent global increase. Phycologia 32 79-99.

HARDING WR (1992) A contribution to the knowledge of South African coastal vleis: The limnology and phytoplankton periodicity of Princess Vlei, Cape Peninsula. Water SA 18 121-130.

HART RC (1988) Zooplankton feeding rates in relation to suspended sediment content: potential influences on community structure in a turbid reservoir. Freshwater Biol. 19 123-139.

HART RC (1992) Aspects of comparative plankton ecology in cascading Mgeni River reservoirs (Midmar, Albert Falls, and Nagle): an overview. South. Afr. J. Aquatic Sci. 18 20-41.

HART RC (1994) Equiproportional temperature-duration responses and thermal influences on distribution and species switching in the copepods Metadiaptomus meridianus and Tropodiaptomus spectabilis. Hydrobiol. 272 163-183.

HART RC (1996) Comparative ecology of plankton in cascading warmwater reservoirs: aspects of relevance to tropical limnology. In: Schiemer F and Boland KT (eds.) Perspectives in Tropical Limnology. SPB Academic Publishing bv, Amsterdam. 113-130.

HART RC (1999) On the limnology of Spioenkop, a turbid reservoir on the upper Thukela River, with particular reference to the structure and dynamics of its plankton community. Water SA 25 519-527. 
HART RC (2000) Comparative long-term periodicity of Diaphanosoma excisum in adjacent warm-water impoundments, with an evaluation of contributory factors. Verh. Int. Ver. Limnol. 27 1933-1939.

HART RC (2001) Two calanoids, two lakes, and a decade or two. An updated record and evaluation of occurrence and periodicity of Tropodiaptomus spectabilis and Metadiaptomus meridianus (Copepoda: Calanoida), and alternative stable states in two cascading impoundments. Hydrobiol. 453 269-283.

HART RC (2004) Cladoceran periodicity patterns in relation to selected environmental factors in two cascading warm-water reservoirs over a decade. Hydrobiol. 526 99-117.

HART RC and HART R (1977) The seasonal cycles of phytoplankton in subtropical Lake Sibaya: A preliminary report. Archiv. für Hydrobiol. 80 85-107.

HOAGLAND P, ANDERSON DM, KAORU Y and WHITE AW (2002) The economic effects of harmful algal blooms in the United States: Estimates, assessment issues, and information needs. Estuaries $\mathbf{2 5}$ 819-837.

KIRK JTO (1983) Light and Photosynthesis in Aquatic Ecosystems. Cambridge University Press, Cambridge. $401 \mathrm{pp}$.

KRUK C, MAZZEO N, LACEROT G and REYNOLDS CS (2002) Classification schemes for phytoplankton: a local validation of a functional approach to the analysis of species temporal replacement. J. Plankton Res. 24 901-912.

LUND JWG, KIPLING C and LE CREN ED (1958) The inverted microscope method of estimating algal numbers and the statistical basis of estimations by counting. Hydrobiol. 11 143-170.

MORIN PJ (1998) Realism, precision, and generality in experimental ecology. In: Resetarits WJ and Bernardo J (eds.) Experimental Ecology. Issues and Perspectives. Oxford University Press, Oxford. $50-70$.

NATIONAL INSTITUTE FOR WATER RESEARCH (1985) The Limnology of Hartbeespoort Dam. South African National Scientific Programmes Report No 110. 269 pp.

PADISÁK J, REYNOLDS CS and SOMMER U (eds.) (1993) Intermediate Disturbance Hypothesis in Phytoplankton Ecology. Kluwer, Dordrecht. 199 pp.

PIETERSE AJH and JANSE VAN VUUREN S (1997) An Investigation Into Phytoplankton Blooms in the Vaal River and the Environmental Variables Responsible for their Development and Decline. WRC Report No 359/1/97. Water Research Commission, Pretoria, South Africa. $245 \mathrm{pp}$

PIETERSE AJH and RÖHRBECK MA (1990) Dominant phytoplankters and environmental variables in Roodeplatt Dam, Pretoria, South Africa. Water SA 16 211-218.

QUINN GP and KEOUGH MJ (2002) Experimental Design and Data Analysis for Biologists. Cambridge University Press, Cambridge. $537 \mathrm{pp}$.

REYNOLDS CS (1984) Phytoplankton periodicity: the interaction of form, function and environmental variability. Freshwater Biol. 14 111-142.

REYNOLDS CS (1995) The Intermediate Disturbance Hypothesis and its applicability to planktonic communities: comments on the views of Wilson and Padisák. New Zeal. J. Ecol. 19 219-225.
REYNOLDS CS (1996) The plant life of the pelagic. Verh. Int. Ver. Limnol. 26 97-113.

REYNOLDS CS (1997) Vegetation process in the pelagic: a model for ecosystem theory. In: Kinne O (ed.) Excellence in Ecology. Ecology Institute, Oldendorf, Germany. 371 pp.

REYNOLDS CS (1999) Phytoplankton assemblages in reservoirs. In: Tundisi JG and Straškraba M (eds.) Theoretical Reservoir Ecology and Its Application. Backhuys Publishers, Leiden. 439-456.

REYNOLDS CS (2005) CEH Windermere Laboratory, The Ferry House, AMBLESIDE, Cumbria, UK. Personal communication - June.

ROJO C, ORTEGA-MAYAGOITIA E and ALVAREZ-COBELAS M (2000) Lack of pattern among phytoplankton assemblages. Or, what does the exception to the rule mean? Hydrobiol. 424 133-139.

ROOS JC and PIETERSE AJH (1996) Seasonal variation of phytoplankton biomass in the Middle Vaal River, South Africa. Water SA 22 33-42.

SEE JH, CAMPBELL L, RICHARDSON TL, PINCKNEY JL, SHEN $\mathrm{R}$ and GUINASSO NL (2005) Combining new technologies for determination of phytoplankton community structure in the northern Gulf of Mexico. J. Phycol. 41 305-310.

SEIP KL and REYNOLDS CS (1995) Phytoplankton functional attributes along trophic gradient and season. Limnol. Oceanogr. $\mathbf{4 0}$ 589-597.

SHAW GR, SUKENIK A, LIVNE A, CHISWELL RK, SMITH MJ and SEAWRIGHT AA (1999) Blooms of the cylindrospermopsin containing cyanobacterium, Aphanizomenon ovalisporum (Forti), in newly constructed lakes, Queensland, Australia. Environ. Toxicol. 14 167-177.

SKULBERG OM (2005) Cyanobacteria/cyanotoxin research - Looking back for the future: The opening lecture of the 6th ICTC. Environ. Toxicol. 20 220-228. (Special Issue).

SOUTHWOOD TRE (1977) Habitat, the template for ecological strategies? J. Animal Ecol. 46 337-365.

STEFFENSEN DA, BURCH M, NICHOLSON BC, DRIKAS M and BAKER PD (1999) Management of toxic blue-green algae (cyanobacteria) in Australia. Environ. Toxicol. 14 183-195.

VOS AT and ROOS JC (2005) Causes and consequences of algal blooms in Loch Logan, an urban impoundment. Water SA 31 385-392.

WALMSLEY RD and BUTTY M 1980 (eds.) Limnology of Some Selected South African Impoundments. Water Research Commission and National Institute for Water Research Report, V\&R Printing Works, Pretoria. 229 pp.

WATSON SB, McCAULEY E and DOWNING JA (1997) Patterns in phytoplankton taxonomic composition across temperate lakes of differing nutrient status Limnol. Oceanogr. 42 487-495.

ZAR JH (1984) Biostatistical Analysis (2 ${ }^{\text {nd }}$ edn.) Prentice-Hall, Englewood Cliffs, New Jersey. 718 pp.

ZOHARY T and ASHTON PJ (1985) The effects of design and operation on the efficiency of hosepipes as water column samplers for phytoplankton. J. Limnol. Soc. South. Afr. 11 5-10.

ZOHARY T, PAISMADEIRA AM, ROBARTS R and HAMBRIGHT KD (1996) Interannual phytoplankton dynamics of a hypertrophic African lake. Archiv. für Hydrobiol. 136 $105-126$. 